\title{
The effect of High Dose of Vitamin D3 on the Prognosis of Patients with Multiple Sclerosis
}

Ledjane Neves de Oliveira', Conceição Walsimary Justa Uchoa2,

Eliane da Silva Grazziano33, Regimar Carla Machado ${ }^{4}$

\section{Abstract}

Introduction: Multiple Sclerosis is a chronic inflammatory neurodegenerative disease of large magnitude in the world.

Method and Goal: To analyze primary studies associating high dose of vitamin $\mathrm{D}$ with the prognosis of patients with multiple sclerosis.

Results: 9 studies were selected, including 1022 participants. 630 of them were randomized to vitamin D3 supplementation in high dose, 171 in low-dose and 221 receiving placebo.

Conclusion: There is evidence that high dose of Vitamin D3 provide immunomodulatory effects in patients with Multiple Sclerosis, showing improvement in the patients' prognosis.

\section{Keywords}

Vitamin D3, High Dose, Multiple Sclerosis.

\section{Introduction}

The number of Multiple Sclerosis patients increased from 2.1 million in 2008 to 2.3 million in 2013. The higher and lower prevalence is in North America and Europe, Sub-Saharan Africa and East Asia, respectively [1]. In Brazil the prevalence average is $8.69 / 100,000$ inhabitants [2].

The disease provides impact on millions of people around the world and in recent years several studies have been conducted in order to investigate the immunomodulatory effects of vitamin $D$ and its relationship with autoimmune diseases.

It is characterized as a chronic inflammatory neurodegenerative disease where environmental and genetic factors, and lifestyle, may 
be potential triggers. Predominant disease of higher latitudes, probably due to the lower solar incidence in winter [3].

In recent years, efforts have been committed to understanding other vitamin $\mathrm{D}$ functions in addition to its participation in bone homeostasis, including immunomodulatory functions. In vitro studies showed that there is significant concentration of vitamin $D$ receptors on $T$ lymphocytes and macrophages, it was also found that 1,25-dihydroxyvitamin $D_{3}$ can suppress experimental autoimmune encephalomyelitis markers, rheumatoid arthritis, systemic lupus erythematosus, type 1 diabetes and inflammatory bowel disease [4].

An experimental study demonstrated that CD8 lymphocytes contain high concentrations of vitamin $D$ receptor, regardless of whether or not enabled. The presence of $1,25-(\mathrm{OH})_{2} \mathrm{D}_{3}$ (active form of vitamin D) in CD8 cell increases the amount of VDR receptor, probably because it improves the longevity and stability of the receptor in vivo as in vitro [5]. The 1.25-dihydroxivitamin $\mathrm{D}$ boosts innate immunity and increases the bacterial death, but also modulates the acquired immunity minimizing inflammation and autoimmune diseases [6].

In view of the magnitude of Multiple Sclerosis and the recent discoveries of the immunomodulatory importance of vitamin D3, we emphasize the importance of conducting an in-depth study on this subject.

The objective of this study is to analyze primary studies associating high dose of vitamin D with the prognosis of patients with multiple sclerosis.

\section{Methods}

The integrative review (RI) is a peculiar form of research in order to generate new knowledge regarding the revised theme. This type of analysis critically summarizes the studied literature and presents a conclusion from the results obtained in each article [7-8]. PRISMA was used as a guide for this RI.

\section{Strategy of election of articles}

The main question of this RI was based on a question using the PICO strategy: "Does the high dosage of vitamin D3 show improvement in prognosis of patients with Multiple Sclerosis?"

The PICO initials are a representation for the patient, intervention, comparison and outcome [9], as shown in the table below: (Table 1)

Table 1. PICO Initials.

\begin{tabular}{|l|r|}
\hline \multicolumn{1}{|c|}{ Population } & Patients with Multiple Sclerosis \\
\hline Intervention & High dose of Vitamin D3 \\
\hline Comparison & Placebo and low dose of vitamin D3 \\
\hline Outcome & Improvement in prognosis \\
\hline
\end{tabular}

Tor search and selection of the studies, we used the PubMed and Clinical Trials databases, and we also used to active search by means of references to other articles.

On Pubmed search strategy and World Health Organization's International Clinical Trials Registry Platform, we used controlled keywords and boolean operators: (Table 2)

Table 2. Pubmed and Clinical Trials search strategy.

Pubmed
(vitamin d3) OR calcitriol) OR cholecalciferol) OR
1 alpha,25-Dihydroxyvitamin D3) OR 1 alpha,25-
Dihydroxyvitamin D3) OR D3, 1 alpha,25-
Dihydroxyvitamin) OR alpha,25-Dihydroxyvitamin D3, 1)
OR 1 alpha,25-Dihydroxycholecalciferol) OR 1 alpha,25
Dihydroxycholecalciferol) OR 1,25-Dihydroxycholecalciferol)
OR 1,25 Dihydroxycholecalciferol) OR
1,25-Dihydroxyvitamin D3) OR 1,25 Dihydroxyvitamin D3))
AND high dose)
(Sclerosis, Multiple) OR Sclerosis, Disseminated) OR
Disseminated Sclerosis) OR MS (Multiple Sclerosis) OR
Multiple Sclerosis) OR Acute Fulminating) Filters: Clinical
Trial
Clinical Trials: May 30th 2016
High dose vitamin D and Multiple Sclerosis

The criteria for inclusion of articles were: adult patients with Relapsing Remitting Multiple Sclerosis or Clinically Isolated Syndrome (CSI), intervention 
with high dose of vitamin D3, randomized clinical trials, study protocols, without language restriction, without time limit of publication.

Exclusion criteria were: review articles and interventions with vitamin D2.

The literature search and eligibility of the items were carried out by two expert reviewers, independently, between June and July 2016. Disagreements were resolved by consensus. A data extraction form was considered, with the following information: title, author, year, journal, location of study, type of study, number of participants, intervention and duration, outcomes and results.

For the analysis of the data, the outcomes and results to answer the research question were considered.

The Figure 1 below shows the sorting of articles.

Figure 1: Flowchart of sorting articles.

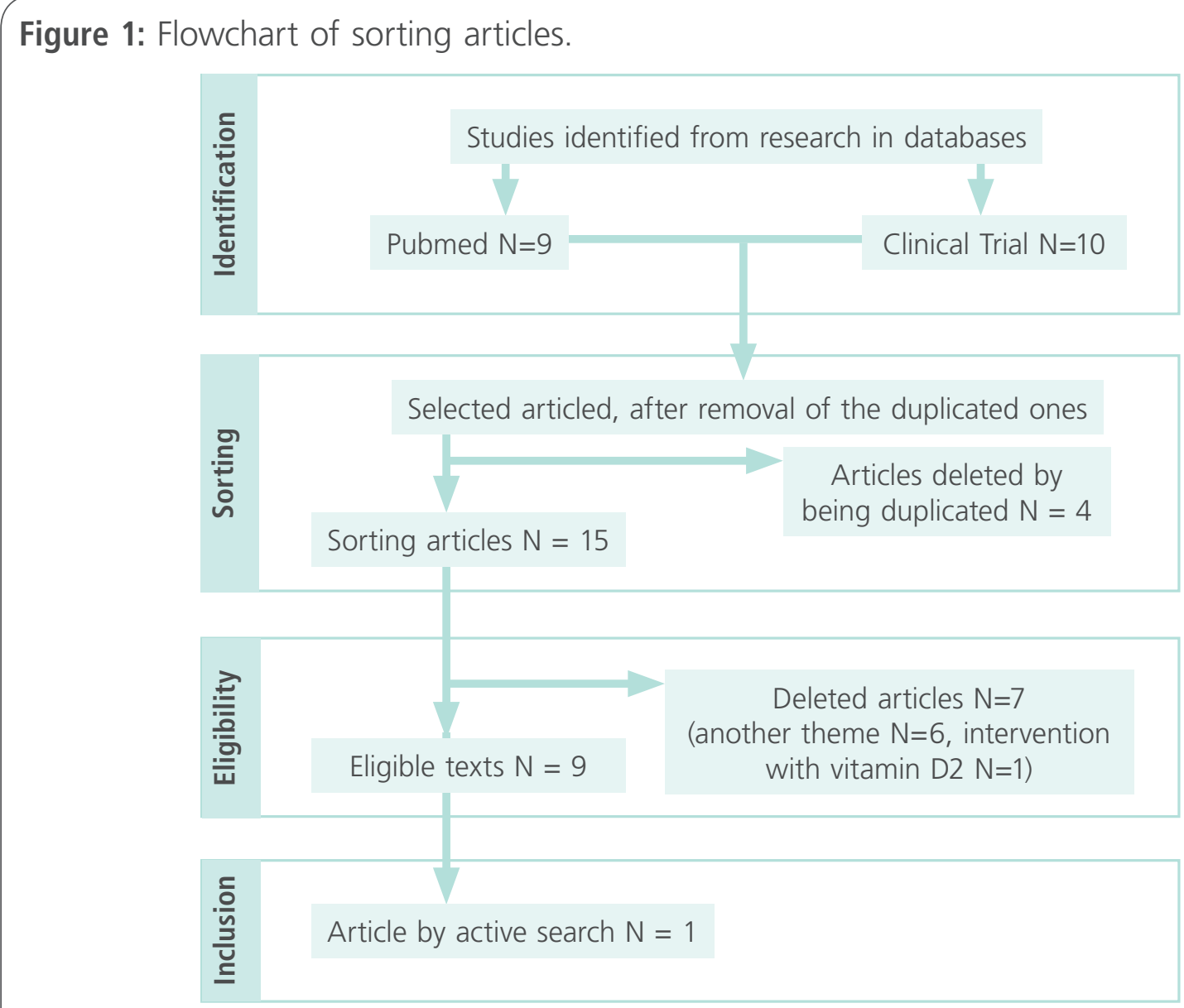

\section{Methodological quality assessment}

For the methodological evaluation of the selected studies we used the scale of Jadad which evaluates five relevant topics, assigning 1 point for each item: the presentation of the study as randomized, the exposure of losses and exclusions, the randomization adequately described, the described and appropriate masking [10].

\section{Results}

\section{General characteristics of the included studies}

9 studies were selected, including 1022 participants, being 630 of them randomized to vitamin D3 supplementation in high dose, 171 of them in lowdose and 221 receiving placebo. The participants of these studies were between 18 and 65 years old. 
Table 2. Methodological quality of included articles.

\begin{tabular}{|l|c|c|c|c|c|}
\hline \multicolumn{1}{|c|}{ Study } & Randomization & Double-blind & Loss and exclusions & $\begin{array}{c}\text { Randomization } \\
\text { methods }\end{array}$ & $\begin{array}{c}\text { Masking } \\
\text { methods }\end{array}$ \\
\hline Jan Dorr et al, 2012 [11] & 1 & 1 & 1 & 1 & 1 \\
\hline Burton et al, 2010 [12] & 1 & 0 & 1 & 1 & 0 \\
\hline Smolders et al, 2011 [13] & 1 & 1 & 1 & 1 & 1 \\
\hline Bhargava et al, 2014 [14] & 1 & 1 & 1 & 1 & 1 \\
\hline Sotirchos et al, 2016 [15] & 1 & 1 & 1 & 0 & 1 \\
\hline Toghianifar et al, 2015 [16] & 1 & 1 & 1 & 0 & 0 \\
\hline Etemadifar, 2015 [17] & 1 & 0 & 0 & 0 & 0 \\
\hline Smolders et al, 2010 [18] & 0 & 0 & 0 & 1 & 1 \\
\hline Golan et al, 2013 [19] & 1 & 1 & 1 & 1 & 0 \\
\hline
\end{tabular}

Table 2 shows the characterization of the studies included in the review. The studies were and are still being conducted in Germany $(n=2)$, in Canada ( $n$ $=2)$, in the Netherlands $(n=1)$, in Norway $(n=1)$, in Italy $(n=1)$, in Switzerland $(n=1)$, in the United States $(n=3)$, in Iran $(n=2)$ and in Israel $(n=1)$. The interventions lasted 02-92 weeks. Five studies received funding from pharmaceutical companies, one of the studies received support from the National Multiple Sclerosis Society; the other 04 studies did not report whether there was financial support from pharmaceutical companies. The studies used placebos or vitamin D3 in low doses (400 to 800 IU) in the control group. The high doses of vitamin D3 varied from 4000 to 600,000 UI.

\section{Methodological quality}

Table 3 shows the methodological quality of included articles. The quality score was 1 to 5. Among the 9 articles evaluated, five were given 5 points,

Table 3. Analysis of the articles included.

\begin{tabular}{|c|c|c|c|c|}
\hline $\begin{array}{l}\text { Studies and } \\
\text { authors }\end{array}$ & $\begin{array}{c}\text { Type of study and } \\
\text { population }\end{array}$ & Intervention & Outcomes/Parameters & Results \\
\hline $\begin{array}{l}\text { Efficacy of } \\
\text { vitamin D } \\
\text { supplementation } \\
\text { in Multiple } \\
\text { Sclerosis ( } \\
\text { EVIDIMS Trial } \\
\text { study protocol } \\
\text { for a randomized } \\
\text { trial [11] } \\
\text { NCT: } 01440062\end{array}$ & $\begin{array}{l}\text { Randomized clinical } \\
\text { trial, controlled, } \\
\text { double-blind, phase } \\
\text { II, pilot study. } \\
\text { Population: } 80 \\
\text { patients with } \\
\text { Multiple Sclerosis } \\
\text { or Clinically Isolated } \\
\text { Syndrome in } \beta \\
\text { Interferon treatment. }\end{array}$ & $\begin{array}{l}25 \text {-hydroxivitamin } \\
\text { D therapy for } 18 \\
\text { months. } \\
40 \text { patients } \rightarrow \\
20.400 \text { UI/day. } \\
40 \text { patients } \rightarrow 400 \\
\text { IU/day }\end{array}$ & $\begin{array}{l}\text { Primary outcome: } \\
\text { Number of new lesions detected by } \\
\text { magnetic resonance images during } \\
\text { treatment with vitamin D3. } \\
\text { Secondary outcome: additional images } \\
\text { of magnetic resonance imaging } \\
\text { and tomography for detection of } \\
\text { neuroinflammation and disease activity. } \\
\text { Evaluation of the safety and tolerance } \\
\text { of high dose of vitamin D3. }\end{array}$ & $\begin{array}{l}\text { It is expected the average reduction of } \\
1.5 \text { new lesions in the treatment with } \\
\text { high dose of vitamin D3 compared } \\
\text { with low-dose. }\end{array}$ \\
\hline $\begin{array}{l}\text { A phase I/II } \\
\text { dose-escalation } \\
\text { trial of vitamin } \\
\text { D3 and calcium } \\
\text { in Multiple } \\
\text { Sclerosis [12] } \\
\text { NCT00644904 }\end{array}$ & $\begin{array}{l}\text { Randomized } \\
\text { prospective clinical } \\
\text { trial phase II. } \\
\text { Population: } 50 \\
\text { patients with } \\
\text { Multiple Sclerosis }\end{array}$ & $\begin{array}{l}25 \text { patients receiving, } \\
\text { initially, } 4,000 \text { UI/day } \\
\text { of vitamin D3 and } \\
\text { increasing to } 40,000 \\
\text { UI/day, } 24 \text { patients } \\
\text { receiving } 4,000 \mathrm{UI} / \\
\text { day of vitamin D3. } \\
\text { Duration of } \\
\text { treatment: } 6 \text { months. }\end{array}$ & $\begin{array}{l}\text { Primary outcome: serum calcium level } \\
\text { to assess the safety of vitamin D3, } \\
\text { comparing the level of calcium between } \\
\text { the groups. } \\
\text { Secondary outcomes: serum measures } \\
\text { of } 25(\mathrm{OH}) \mathrm{D} \text {, immunological markers, } \\
\text { relapse, and Expanded Disability Status } \\
\text { score (EDSS). }\end{array}$ & $\begin{array}{l}\text { Calcium levels were normal in both } \\
\text { groups. There was a peak of } 25(\mathrm{OH}) \\
\text { D of } 413 \mathrm{nmol} / \mathrm{L} \text { in the intervention } \\
\text { group, but there were no adverse } \\
\text { events. The treatment group had fewer } \\
\text { relapses and pertinacious decrease in } \\
\text { the growth of T cell. } \\
\text { High dose of vitamin D3 is safe and } \\
\text { has immunoregulatory effects in } \\
\text { Multiple Sclerosis. }\end{array}$ \\
\hline
\end{tabular}




\begin{tabular}{|c|c|c|c|c|}
\hline Studies and authors & $\begin{array}{l}\text { Type of study and } \\
\text { population }\end{array}$ & Intervention & Outcomes/Parameters & Results \\
\hline $\begin{array}{l}\text { Efficacy of Vitamin D3 as add } \\
\text { therapy in patients with Relapsing } \\
\text { Remitting Multiple Sclerosis } \\
\text { receiving subcutaneous interferon } \\
\text { beta 1a: a phase II, multicenter, } \\
\text { double-blind, randomized, } \\
\text { placebo-controlled trial (SOLAR) } \\
\text { [13] } \\
\text { NCT01285401 }\end{array}$ & $\begin{array}{l}\text { Randomized clinical trial, } \\
\text { multicenter, double-blind, } \\
\text { placebo-controlled, three-arm. } \\
\text { Population: } 348 \text { patients with } \\
\text { Relapsing Remitting Multiple } \\
\text { Sclerosis and vitamin D3 level } \\
<150 \mathrm{nmol} / \mathrm{L} \text {. }\end{array}$ & $\begin{array}{l}174 \text { patients receiving IFN beta- } 1 \mathrm{a} \text {, } \\
44 \mu \mathrm{g}, \mathrm{sc}, 3 \mathrm{x} \text { a week and } 7000 \\
\mathrm{UI} \text { per } 4 \text { weeks and } 14,000 \text { UI of } \\
\text { vitamin } \mathrm{D} 3 \text { for } 92 \text { weeks. } \\
174 \text { patients receiving IFN beta- }{ }^{a}{ }^{a} \\
44 \mu \mathrm{g}, \mathrm{sc}, 3 \mathrm{x} \text { a week and placebo. }\end{array}$ & $\begin{array}{l}\text { Primary outcomes: } \\
\text { Through functional magnetic resonance } \\
\text { imaging, evaluating the number of injuries in } \\
48 \text { weeks, the number of relapses and disease } \\
\text { progression. } \\
\text { Secondary outcomes of functional magnetic } \\
\text { resonance imaging: evaluation of the anti- } \\
\text { inflammatory effect of vitamin D3 in the } \\
\text { lesions and progression of the disease. }\end{array}$ & $\begin{array}{l}\text { According to the authors, initial studies show that } \\
\text { vitamin D3 dose intended for use in this study is } \\
\text { beneficial and safe for patients with Multiple Sclerosis. }\end{array}$ \\
\hline $\begin{array}{l}\text { The vitamin D to ameliorate } \\
\text { Multiple Sclerosis (VIDAMS) trial: } \\
\text { study design for a multicenter } \\
\text { randomized, double-blind } \\
\text { controlled trial of vitamin D in } \\
\text { Multiple Sclerosis [14] } \\
\text { NCT: } 01490502\end{array}$ & $\begin{array}{l}\text { Prospective clinical trial, } \\
\text { randomized, double-blind. } \\
\text { Population: } 172 \text { patients with } \\
\text { Relapsing Remitting Multiple } \\
\text { Sclerosis }\end{array}$ & $\begin{array}{l}\text { Patients will be divided into two } \\
\text { groups: } 86 \text { patients receive low-dose } \\
\text { of vitamin D3 ( } 600 \text { Ul/day) versus } 86 \\
\text { patients receiving high dose ( } 5000 \\
\text { Ul/day) for } 2 \text { years. } \\
\text { All patients will receive } 20 \mathrm{mg} / \text { day } \\
\text { glatiramer acetate. }\end{array}$ & $\begin{array}{l}\text { The number of relapses and of new lesions in } \\
\text { the brain will be assessed, as well as the brain } \\
\text { volume, the direct action of vitamin D3 on } \\
\text { cerebral atrophy, through functional magnetic } \\
\text { resonance imaging. }\end{array}$ & $\begin{array}{l}\text { The study is ongoing and the authors state that it } \\
\text { will bring insightful information about the safety and } \\
\text { effectiveness of vitamin D in Multiple Sclerosis. }\end{array}$ \\
\hline $\begin{array}{l}\text { Safety and immunologic effects of } \\
\text { high vs low dose cholecalciferol in } \\
\text { Multiple Sclerosis [15] } \\
\text { NCT: } 01024777\end{array}$ & $\begin{array}{l}\text { Randomized clinical trial, } \\
\text { double-blind, unique center, } \\
\text { pilot study. } \\
\text { Population: } 40 \text { patients with } \\
\text { Multiple Sclerosis }\end{array}$ & $\begin{array}{l}\text { High dose group: } 19 \text { patients } \\
\text { received } 10400 \text { Ul/day of vitamin } \\
\text { D3. } \\
\text { Low dose group: } 21 \text { patients } \\
\text { received } 400 \mathrm{UI} \text { of vitamin D3. Both } \\
\text { groups received the intervention for } \\
6 \text { months. In addition to vitamin D, } \\
\text { they all received } 1000 \text { mg calcium/ } \\
\text { day. }\end{array}$ & $\begin{array}{l}\text { Primary outcome: change in proportion of } \\
\text { IFN-y and T cells CD } 4+\text { in the high-dose } \\
\text { group compared to the low-dose group. } \\
\text { Frequency of adverse events in both groups. } \\
\text { Secondary outcomes: changes in other } \\
\text { subtypes of immune cells. } \\
\text { The classification of the evidence of these } \\
\text { outcomes is class I. }\end{array}$ & $\begin{array}{l}\text { The level of } 25(\mathrm{OH}) \mathrm{D} \text { has increased more in the high- } \\
\text { dose group. } \\
\text { There was } 1 \text { relapse in both groups. } \\
\text { High dose of vitamin D3 reduces the proportion of } \\
\text { IFN- } \gamma \text { and T CD4 +IL-17. There was a decrease in the } \\
\text { proportion of IFN- } \gamma \text { and T CD4 +IL-17 in relation to the } \\
\text { low-dose group. } \\
\text { There was a decrease in CD161 cells +CD4 + the high- } \\
\text { dose group, but not in the low-dose group. } \\
\text { Reduction in IL-17 correlated with an increase in the } \\
\text { level of vitamin D3. }\end{array}$ \\
\hline $\begin{array}{l}\text { Effect of high } \\
\text { dose vitamin D intake on } \\
\text { interleukin-17 levels in multiple } \\
\text { sclerosis: a } \\
\text { randomized, double-blind, } \\
\text { placebo-controlled clinical trial [16] }\end{array}$ & $\begin{array}{l}\text { Randomized clinical trial, } \\
\text { double-blind, placebo- } \\
\text { controlled. } \\
\text { Population: } 94 \text { patients with } \\
\text { Multiple Sclerosis. }\end{array}$ & $\begin{array}{l}47 \text { patients with RRMS receiving } \\
50,000 \text { UI of vitamin D3 every } 5 \\
\text { days for } 12 \text { weeks. } \\
\text { Placebo group: } 47 \text { patients received } \\
\text { placebo for } 12 \text { weeks. }\end{array}$ & $\begin{array}{l}\text { Comparison of the levels of IL-17 in the } \\
\text { intervention group and placebo. } \\
\text { Evaluation of vitamin D3 and calcium levels in } \\
\text { both groups. }\end{array}$ & $\begin{array}{l}\text { After } 12 \text { weeks, the serum level of IL-17 increased by } \\
60 \% \text { in the placebo group and decreased by } 40 \% \text { in the } \\
\text { intervention group. } \\
\text { The levels of calcium and vitamin D3 did not increase } \\
\text { abnormally. }\end{array}$ \\
\hline
\end{tabular}




\begin{tabular}{|c|c|c|c|c|}
\hline $\begin{array}{l}\text { Studies and } \\
\text { authors }\end{array}$ & $\begin{array}{l}\text { Type of study and } \\
\text { population }\end{array}$ & Intervention & Outcomes/Parameters & Results \\
\hline $\begin{array}{l}\text { High dose oral } \\
\text { versus intramuscular } \\
\text { vitamin D3 } \\
\text { supplementation } \\
\text { in Multiple } \\
\text { Sclerosis[17] } \\
\text { NCT: } 02696590\end{array}$ & $\begin{array}{l}\text { Clinical trial, } \\
\text { randomized, open } \\
\text { masking (open label). } \\
\text { Population: } 200 \\
\text { patients }\end{array}$ & $\begin{array}{l}\text { Patient with MS } \\
\text { receiving vit. D3 } \\
\text { injectable and oral, } \\
600,000 \text { UI in } 2 \\
\text { weeks. } \\
\text { Healthy groups: } \\
\text { receiving } 600,000 \text { UI } \\
\text { of vit. D3 injectable } \\
\text { and oral, in } 2 \text { weeks. }\end{array}$ & $\begin{array}{l}\text { Primary outcome: serum concentration } \\
\text { of vitamin D3. }\end{array}$ & $\begin{array}{l}\text { The study is ongoing and intend to } \\
\text { evaluate which are the results of } \\
\text { the feasibility of oral and injectable } \\
\text { routes, and whether there will be } \\
\text { toxicity intervention. }\end{array}$ \\
\hline $\begin{array}{l}\text { Safety and T cell } \\
\text { modulating effects } \\
\text { of high dose vitamin } \\
\text { D3 supplementation } \\
\text { in Multiple Sclerosis. } \\
\text { Study protocol [18] } \\
\text { NCT: } 00940719\end{array}$ & $\begin{array}{l}\text { Protocol of study held } \\
\text { with } 15 \text { patients with } \\
\text { Relapsing Remitting } \\
\text { Multiple Sclerosis }\end{array}$ & $\begin{array}{l}15 \text { patients were } \\
\text { supplemented with } \\
20,000 \text { UI/day of } \\
\text { vitamin D3 for } 12 \\
\text { weeks. }\end{array}$ & $\begin{array}{l}\text { Primary outcome: Regulation of T cells. } \\
\text { Secondary outcomes: evaluation of } \\
\text { the levels of vitamin D3 and calcium } \\
\text { metabolism. }\end{array}$ & $\begin{array}{l}\text { The researchers found satisfactory } \\
\text { correlation between regulation } \\
\text { of T cells and the level of vitamin } \\
\text { D. There was an increase in the } \\
\text { proportion of CD4 cells+IL10+ and } \\
\text { a decrease in the rate of IFN- } \gamma \text { e } \\
\text { CD4+IL4+. }\end{array}$ \\
\hline $\begin{array}{l}\text { Vitamin D } \\
\text { supplementation for } \\
\text { patients with } \\
\text { multiple sclerosis } \\
\text { treated with } \\
\text { interferon-beta: } \\
\text { a randomized } \\
\text { controlled trial } \\
\text { assessing the } \\
\text { effect on flu-like } \\
\text { symptoms and } \\
\text { immunomodulatory } \\
\text { properties [19] } \\
\text { NCT01005095 }\end{array}$ & $\begin{array}{l}\text { Randomized clinical } \\
\text { trial, double-blind, } \\
\text { controlled. } \\
\text { Population: } 45 \\
\text { patients with } \\
\text { MS treated with } \\
\text { interferon-beta. }\end{array}$ & $\begin{array}{l}21 \text { patients received } \\
800 \text { UI of vit. D3/day. } \\
24 \text { patients received } \\
4,370 \text { UI/day of vit. } \\
\text { D3 for } 1 \text { year, both } \\
\text { groups. }\end{array}$ & $\begin{array}{l}\text { Primary outcome: test how } \\
\text { supplementation with vit. D3 can } \\
\text { improve symptoms of interferon } \\
\text { induced flu. } \\
\text { Secondary outcome: to evaluate the } \\
\text { safety and tolerance of vit. Evaluate } \\
\text { the effectiveness of the supplement } \\
\text { determined by the rate of relapse and } \\
\text { EDSS and the level of cytokines, such } \\
\text { as: IFN- }, \text { IL-10 and IL-17. }\end{array}$ & $\begin{array}{l}\text { After } 3 \text { months of supplementation } \\
\text { there was a significant increase of } \\
\text { vit. D3 in both groups. } \\
\text { PTH decreased in high-dose group } \\
\text { of vit. D3 and did not change in } \\
\text { a significant way in the low dose } \\
\text { group. } \\
\text { The calcium level remained within } \\
\text { the normal range. } \\
\text { No significant change was noted in } \\
\text { the severity of flu-like symptoms. } \\
\text { There was no significant change in } \\
\text { EDSS scores or relapse rate in both } \\
\text { groups. }\end{array}$ \\
\hline
\end{tabular}

one received 2 points, two received 3 points and one received 1 point. It should be noted that studies with score lower than 3 points are considered methodologically poor.

\section{Discussion}

Studies and sample protocols of that review showed that the reduction of injuries is expected in the intervention group with high dose of vitamin D3 [11], calcium levels remained normal, and there were no adverse effects [12-19]. It demonstrated that treatment with high dose of vitamin D3 lowers the proportion of IFN- $\gamma$ and TCD4 +IL-17 and is safe. There was a decrease in CD161 cells +CD4
+ the high-dose group, but not in the low-dose group. It showed a decrease in IL-17 with increased of vitamin D3 [15]. A satisfactory correlation was observed between the regulation of $T$ cells and the level of vitamin D3, there was an increase in the proportion of $\mathrm{CD}^{+}{ }^{+} \mathrm{LL}-10$ and a decrease in the rate of IFN- $\gamma$ and $\mathrm{CD}^{+}{ }^{+} \mathrm{IL}-4^{+}[18]$.

In 1983 for the first time a publication said that there was vitamin D3 receptors in peripheral blood cells, marking the beginning of the relation with the immunomodulatory functions [4].

An in vitro study demonstrated that the administration of vitamin D3 to diseased cells by Experimental Autoimmune Encephalomyelitis (EAE) blocked the progression of the disease in rats. In $E A E$, 
inflammatory TH1 cells attack the myelin sheath, as well as in Multiple Sclerosis. The results show that the 1.25- $(\mathrm{OH})_{2} \mathrm{D}_{3}$ can be an innovative and effective treatment for Multiple Sclerosis [20].

High dose of vitamin D3 has been shown to be safe up to $40,000 \mathrm{UI} /$ day. It points out that in the absence of sunlight, a physiological dose of 10,000 $\mathrm{UI} /$ day is necessary, in order to keep this vitamin in adequate levels [21].

In Canada, a study is being conducted in which the subject has received 40,000 Ul/day of vitamin D3 for six months, showing the peak of $25(\mathrm{OH}) \mathrm{D}$ of $413 \mathrm{nmol} / \mathrm{L}$ in the intervention group, but without adverse events. Hepatic and renal functions were assessed by measurement of liver enzymes, urea and creatinine. There was no renal calcification by means of ultrasound [12].

In another study which is being developed in Germany, patients are being divided into two groups which will receive high-dose and low-dose of vitamin D3, for 2 years. We want to compare the effectiveness of vitamin D3 in high dose compared to low dose in patients with Multiple Sclerosis. A reduction of 1.5 new lesions in high-dose treatment is expected. The authors point out that the vitamin is safe, the treatment is cheap and that this study can fill the gaps that still exist regarding the immunomodulatory effects on Multiple Sclerosis [11].

Certainly the effects and protective modulators that vitamin D3 exerts on the immune system are the reasons why in vivo and in vitro studies have demonstrated positive effects in the treatment of Multiple Sclerosis [15-20].

Another study showed that calcium levels remained normal between groups. There was a peak of $25(\mathrm{OH}) \mathrm{D}$ of $413 \mathrm{nmol} / \mathrm{L}$ in the intervention group, but there were no adverse events. The treatment group had fewer relapses and pertinacious decrease in the growth of T cell [12].

In Australia a cohort study with 145 participants lasting 2.3 years investigated the relationship between the level of $25-\mathrm{OH}-\mathrm{D}$ and relapses in patients with Multiple Sclerosis, and it was observed that there was a decline in the risk of relapse for each $\mathrm{nmol} / \mathrm{L}$ increased in the rate of vitamin D3 [3].

The first major international placebo-controlled study being conducted to assess the effectiveness of vitamin $\mathrm{D}$ as additional therapy in patients with Multiple Sclerosis and changes in clinical standards and MRI [13].

Studies present the dose of vitamin D3, $7000 \mathrm{UI}$ for 4 weeks and 14,000 UI for 92 weeks, to be used in this study, is safe, and it confirms what previous studies have found, the absence of hypercalcemia, hypercalciuria which could have been triggered by high doses of vitamin D [12-22].

In a study that is being carried out in the United States, participants, persons with Multiple Sclerosis, are receiving high dose of vitamin D3 and the researchers wish to assess the number of relapses and new lesions on the brain and the direct action of vitamin D3 on cerebral atrophy through magnetic resonance imaging [14].

A cohort study with duration of 5 years assessed 2,362 MRIs of 469 subjects suffering from Multiple Sclerosis and aimed to establish whether the level of vitamin $D$ is associated with brain damage, inflammation and progression of the disease, and it was found that for every $10 \mathrm{ng} / \mathrm{ml}$ increase in serum vitamin $D$, the risk of the development of new lesions was 15\% lower. Therefore, the level of vitamin D3 is inversely related to the activity of Multiple Sclerosis in the brain. There was also a lower risk of relapse to each serum increase of $10 \mathrm{ng} / \mathrm{ml}$ of vitamin D3 [23].

At the University of California, a study has been developed with 15 patients who received 20,000 UI/day of vitamin D for 12 weeks and it observed an increase in the proportion of $\mathrm{T} \mathrm{IL-10} \mathrm{cells} \mathrm{S}^{+} \mathrm{CD} 4$ and a decrease in the rate of IFN- $\gamma+$ and $\mathrm{T}$ IL- 4 cell. These results corroborate the effect that vitamin D3 is a modulator of the immune system [18].

In an in vitro study, vitamin D3 prevented the proliferation of proinflammatory cytokines, such as: IFN- $\gamma$ and IL-17, raised the production of anti-inflammatory cytokines, IL-4 and IL-10 and promoted the adjustment in T lymphocytes [24]. 
Experiment studies confirmed that the active form of vitamin D3, 1.25-dihydroxivitamina D (1.25 $(\mathrm{OH}) 2 \mathrm{D})$ blocks the proliferation of $\mathrm{TH} 1$ and $\mathrm{TH} 17$ (IL-17), both producing inflammatory cytokines and promotes the increase of $\mathrm{TH} 2$ cells and Tregs (regulatory $\mathrm{T}$ cells) that produce anti-inflammatory substances (IL-4, IL-10) and regulating the immune system, respectively [24-25].

At the University of Medical Sciences in Iran, a clinical trial randomized controlled double-blind stu$d y$ is being conducted in a group of patients that is receiving $50,000 \mathrm{UI}$ of vitamin D3 every 5 days for 12 weeks. After 12 weeks, the serum level of IL-17 increased by $60 \%$ in the placebo group and decreased by $40 \%$ in the intervention group, and calcium and vitamin D3 levels did not increase abnormally [16].

On Switzerland another in vitro study confirms that vitamin D3 was able to reduce inflammatory cytokines, such as: IL-17, TNF- $\alpha$ and IFN-y [26].

In phase I/II of a randomized clinical trial, the levels of calcium and vitamin D3 did not increase in an excessive way confirming what other studies have demonstrated: safety and tolerability of high doses of vitamin D3 in treatment of patients with Multiple Sclerosis [12-19].

A clinical trial is being conducted in Iran and patients with Multiple Sclerosis are getting vitamin D3 in high doses in oral and injectable form. 200 subjects of both genres are being recruited, adults aged between 25 and 59 years and with serum concentration of $25(\mathrm{OH}) \mathrm{D} 3 \geq$ of $20 \mathrm{ng} / \mathrm{ml}$. This study aims to evaluate the feasibility of oral and injectable routes, the serum concentration of vitamin D3 and whether toxicity [17].

In a prospective randomized study in Turkey, the safety and efficacy of supplementation of a single mega dose of $600,000 \mathrm{IU}$ of vitamin D3 in the oral and intramuscular way was evaluated, in elderly older than or 65 years old. It was found that in the 12 th week, after administration of the supplement, $83.3 \%$ of patients on oral and $100 \%$ of them in intramuscular form were maintaining adequate levels of vitamin D [27].

In Israel, the researchers evaluated the efficacy and safety of vitamin D3 in combating flu symptoms in patients who made use of interferon beta. Patients received low and high dose vitamin D3 for a year. It was noted that the level of vitamin D3 increased after 3 months of the start of supplementation, the PTH decreased in the high-dose group and did not change significantly in the lowdose group, the calcium level remained within the normal standards, there was no change in the rate of relapse of Multiple Sclerosis, and no change was noted in the general flu symptoms. The authors state that although no beneficial results of vitamin $D$ were obtained in relation to flu-like symptoms induced by the INF-beta, the study provides support to its immunomodulatory properties, and they conclude that vitamin D3 influences the secretion of IL-17 and that depends on the dose of the intervention [19].

A study conducted in the United States found that there was a decrease in the production of IL-17 by CD4 T cells and B lymphocytes [15].

\section{Conclusion}

On the basis of the studies selected for this review, even though some of them are still in progress, the results showed that treatment with high dose of vitamin D3 presents beneficial, safe and immunomodulatory effects in multiple sclerosis, showing improvement in prognosis of patients.

It should be noted, however, that the completion of clinical trials is essential for the treatment to be consolidated and to be adopted in practice.

One aspect to highlight is the need for greater investments in clinical trials, since some have limited number of participants, in order to strengthen the evidence of treatment with high dose of vitamin D3. 


\section{References}

1. Atlas: Multiple Sclerosis Resources in the World 2008. Geneva, Switzerland: World Health Organization; 2008. Available at: http://www.msif.org/about-ms/publicationsand-resources/.

2. Pereira ABCNG, Lacativa MCS, Pereira FFCC, Alvarenga RMP. Prevalence of multiple sclerosis in Brazil: A systematic review. Multiple Sclerosis and Related Disorders. 2015; 4: 572-9.

3. Simpson S Jr, Taylor B, Blizzard L, PonsonbyAL,PittasF,Tremlett $\mathrm{H}$ et al. Higher 25-hydroxyvitamin D Is Associated with Lower Relapse Risk in Multiple Sclerosis. Ann Neurol. 2010; 68:193203. doi: 10.1002/ana.22043.

4. Bahlla AK, Amento EP, Clemens TL, Holick MF, Krane SM. Specific high-affinity receptors for 1,25-dihydroxyvitamin d- in human peripheral blood mononuclear cells: presence in monocytes and induction in tymphocytes following activation. Journal of Clinical Endocrinology and Metabolism. 1983; 57: 1308-1310. DOI: 10.1210/jcem-57-6-1308.

5. Deluca HF, Cantorna MT. Vitamin D: its role and uses in immunology. Faseb J. 2001; 15:2579-2585.DOI: 10.1096/fj.010433rev.

6. Adams, J S, Hewison, M. Unexpected actions of vitamin D: new perspectives on the regulation of innate and adaptive immunity. Nature clinical practice Endocrinology \& metabolism. 2008; 4: 80-90. doi:10.1038/ncpendmet0716.

7. Torraco RJ. Writing Integrative Literature Reviews: Guidelines and Examples. Human Resource Development Review. 2005; 3 : 356-367.doi: 10.1177/1534484305278283

8. Pompeo DA, Rossi LA, Galvão CM. Revisão integrativa: etapa inicial do processo de validação de diagnóstico de enfermagem. Acta Paul Enferm. 2009; 22:434-8. dx.doi.org/10.1590/s010321002009000400014

9. Santos CMC, Pimenta CAM, Nobre MRC. A estratégia Pico para a construção da pergunta de pesquisa e busca de evidências. Rev Latino-Am Enfermagem. 2007; 15:508-511. dx.doi.org/10.1590/ S0104-11692007000300023.

10. Jadad AT, Moore RA, Carrol D, Jenkinson C, Reynolds DJ, Gavaghan DJ, et al. Assessing the quality of reports of randomized clinical trials: Is Blinding necessary? Control Clin Trials. 1996; 17:1-12. PMID: 8721797.

11. Dörr J, Ohlraun S, Skarabis H, Friedemann P. Efficacy of Vitamin D Supplementation in Multiple Sclerosis (EVIDIMS Trial): study protocol for a randomized controlled trial. Trials 2012. Available from: http://www.trialsjournal.com/content/13/1/15. doi: 10.1186/1745-6215-13-15.

12. Burton JM, Kimball S, Vieth R, Bar-Or A, Dosch HM, Cheung R. A phase I/II dose-escalation trial of vitamin D3 and calcium in multiple sclerosis. Neurology. 2010; 74: 1852-1859.doi: 10.1212/WNL.0b013e3181e1cec2.
13. Smolders J, Hupperts R, Barkhof F, Grimaldi LME, Holmoy T, Killestein $J$ et al. Efficacy of vitamin D3 as add-on therapy in patients with relapsing-remitting multiple sclerosis receiving subcutaneous interferon beta 1 a: a phase II, multicenter, double-blind, randomized, placebo-controlled trial. J Neurol Sci.2011; 1-6. doi:10.1016/j.jns.2011.04.

14. Bhargava P, Cassard S, Steele SU, Azevedo C, Pelletier D, Sugar EA et al.The vitamin D to ameliorate Multiple Sclerosis (VIDAMS) trial: study design for a multicenter randomized, double-blind controlled trial of vitamin D in Multiple Sclerosis. Contemporary ClinicalTrials. 2014; 39: 288-293. doi: 10.1016/j.cct.2014.10.004

15. Sotirchos ES, Bhargava P, Eckstein C, Haren KV, Baynes M, Nitranos A et al. Safety and immunologic effects of high-vs lowdose cholecalciferol in multiple sclerosis. Neurology. 2016; 86: 1-10. doi: 10.1212/WNL.0000000000002316

16. Toghianifar N, Ashtari F, Esfahani SHZ, Mansourian M et al. Effect of high dose vitamin D intake on interleukin-17 levels in multiple sclerosis: a randomized, double-blind, placebocontrolled clinical trial. Journal of Neuroimmunology. 2015; 285:125-128. doi: 10.1016/j.jneuroim.2015.05.022

17. Etemadifar M. High dose oral versus intramuscular vitamin D3 supplementation in Multiple Sclerosis. 2015. Avaliable from: https://clinicaltrials.gov/show/NCT02696590.

18. Smolders J, Peelen E, Thewissen M, Cohen Tervaert JW, Menheere P, Hupperts R et al. Safety and T Cell Modulating Effects of High Dose Vitamin D3 Supplementation in Multiple Sclerosis. PLoS ONE. 2010; 5: 1-9. doi:10.1371/journal.pone.0015235. 10.1371/ journal.pone.0015235.

19. Golan D, Halhal B, Glass-Marmor L, Staun-Ram E, Rozenberg O, Lavi I et al. Vitamin D supplementation for patients with multiple sclerosis treated with interferon-beta: a randomized controlled trial assessing the effect on flu-like symptoms and immunomodulatory properties. BMC Neurology. 2013; 13:1-10. doi: 10.1186/1471-2377-13-60.

20. Cantorna M, Hayes C, Deluca H. 1,25-Dihydroxyvitamin D3 reversibly blocks the progression of relapsing encephalomyelitis, a model of multiple sclerosis. Proc. Natl. Acad. Sci. 1996; 93: 7861-7864. PMCID: PMC38839

21. Vieth R. Vitamin D supplementation, 25-hydroxyvitamin D concentrations, and safety.Am J ClinNutr. 1999; 69:842-56. PMID:10232622

22. Kimball SM, Ursell MR, O'Connor P, Vieth R. Safety of vitamin D3 in adults with multiple sclerosis. Am J Clin Nutr.2007; 86:645-51. PMID: 17823429. 
23. Mowry EM et al. Vitamin D status predicts new brain magnetic resonance imaging activity in multiple sclerosis. Annals of Neurology. 2012; 72: 1-12. doi: 10.1002/ana.23591.

24. Smolders J, Damoiseaux J, Menheere P, Hupperts R. Vitamin $D$ as an immune modulator in multiple sclerosis, a review. J Neuroimmunol 2008; 194: 7-17.doi: 10.1016/j. jneuroim.2007.11.014.

25. Correale J, Ysrraelit MC, Gaita'n MI. Immunomodulatory effects of vitamin D in multiple sclerosis. Brain. 2009; 132: 1146-1160. doi: 10.1093/brain/awp033

26. Lysandropoulos AP, Jaquiery E, Jilek S, Pantaleo G, Schluep M, DuPasquierRA.Vitamin $D$ has a direct immunomodulatory effect on CD8+ T cells of patients with early multiple sclerosis and healthy control subjects. J. Neuroimmunol. 2011; 233: 240-244. doi:10.1016/j.jneuroim.2010.11.008.

27. Tellioglu A, Basaran S, Seydaoglu G. Efficacy and safety of high dose intramuscular or oral cholecalciferol in vitamin D deficient/ insufficient elderly. Maturitas. 2012; 72:332-8. doi: 10.1016/j. maturitas.2012.04.011.

Publish in International Archives of Medicine

International Archives of Medicine is an open access journal publishing articles encompassing all aspects of medical science and clinical practice. IAM is considered a megajournal with independent sections on all areas of medicine. IAM is a really international journal with authors and board members from all around the world. The journal is widely indexed and classified Q2 in category Medicine. 